\title{
The Role of the A/r/tography Method in Art Teacher Training
}

\author{
Nurhayat Güneş ${ }^{1, *}$, Şeniz Aksoy ${ }^{2}$, Vedat Özsoy ${ }^{3}$ \\ ${ }^{1}$ Department of Fine Arts Education, Dicle University, Diyarbakır, Turkey \\ ${ }^{2}$ Department of Fine Arts Education, Gazi University, Ankara, Turkey \\ ${ }^{3}$ Department of Art and Design, TOBB Economy and Technology University, Ankara, Turkey
}

Received May 26, 2020; Revised July 29, 2020; Accepted August 10, 2020

\section{Cite This Paper in the following Citation Styles}

(a): [1] Nurhayat Güneş, Şeniz Aksoy, Vedat Özsoy , "The Role of the A/r/tography Method in Art Teacher Training," Universal Journal of Educational Research, Vol. 8, No. 10, pp. 4909 - 4919, 2020. DOI: 10.13189/ujer.2020.081063.

(b): Nurhayat Güneş, Şeniz Aksoy, Vedat Özsoy (2020). The Role of the A/r/tography Method in Art Teacher Training. Universal Journal of Educational Research, 8(10), 4909 - 4919. DOI: 10.13189/ujer.2020.081063.

Copyright $\odot 2020$ by authors, all rights reserved. Authors agree that this article remains permanently open access under the terms of the Creative Commons Attribution License 4.0 International License

\begin{abstract}
The main aim of this research is to determine the opinions of students and the faculty offering the course on the $\mathrm{a} / \mathrm{r} /$ tography applications. This descriptive study was carried out during the Spring semester of the 2016-2017 school year and the Fall semester of the 2017-2018 school year at the Department of Art Education of Gazi Faculty of Education in Gazi University. The participants of the research were 7 students and the faculty member offering the course. Descriptive analysis was the method used to analyze the data. According to the research results, using personal life experiences in $\mathrm{a} / \mathrm{r} / \mathrm{tog}$ raphical practices helped students create original and creative works. The students developed significantly in associating real life with awareness of their own experiences, although they found it challenging to write, produce ideas, and generate meaning during the application section of the course. The activities effectively unveiled students' roles as artists/researchers/teachers-learners. According to the faculty member offering the course, students could refer to their own experiences to generate original and creative ideas during application. Students carried out research work, however limited, as researchers. Students thought and acted like artists, creating works of high artistic values. Students acted as learners - they learned during the course and beyond. Students also acted as teachers by learning from one another. Due to a lack of thinking and inquiry-based teaching in traditional art education primarily in art studios and a lack of previous opportunities to focus on and write about experiences, students had difficulty understanding subjects, generating ideas, and writing.
\end{abstract}

Keywords Art Teacher Training, A/r/tography, Living Inquiry, Arts-based Research, Arts-based Educational Research

\section{Introduction}

Education is a dynamic process, which often changes and improves. Therefore, just as all fields witness developments over time, new approaches in education are also inevitable. In the last two decades, the a/r/tography approach has emerged in the field of art education; $\mathrm{a} / \mathrm{r} / \mathrm{tography}$ is a form of art-based research.

Art-based research represents a practice-based research approach that supersedes disciplines, opening new fields for collaboration [1-5]. "Just as science assists art-based research through its emphasis on systematic inquiry, art enhances the process of discovery in science by its responsiveness to the unexpected" [6]. Watrin illumines similarities between qualitative research and art practice in stating that both the artist and the researcher draw meaning from, interpret, define and study lived experiences [7]. Thus, it is possible to say that art and science disciplines assist each other within research.

Art-based Educational Research-an extension of art-based research-includes the study of artistic creation in educational research. According to Barone and Eisner [8], art-based educational research means developing perspectives on educational activities through art-based research. 
A/r/tography, a methodology covering two concurrent research practices-art application and education-focuses on the process rather than the result. $\mathrm{A} / \mathrm{r} /$ tografi is a pedagogical strategy as well as a methodological framework for research studies [9-17]. A/r/tography once took the form "live(d) curricula", which Aoki [18] developed in the field of art education.

The term "a/r/tography" was derived by placing slash marks "/" between the initial letters of "artist, researcher and teacher" roles and annexing "graphia," which is the Greek word for writing. The term thus starts with $\mathrm{a} / \mathrm{r} / \mathrm{t}$, associating it with the word "art," which is not a coincidence. In a/r/tography, research is inquiry-based, occurring within artist, researcher and teacher roles in conjunction with art and writing -in other words, textual and artistic processes.

$\mathrm{A} / \mathrm{r} /$ tography intertwines artist, researcher, and teacher roles (as well as other possible roles, which appropriately include the learner role); these roles are paired with theoretical, practicable and creative knowledge to unveil deeper meanings, as opposed to facts, in time $[11,19]$. In essence, $\mathrm{a} / \mathrm{r} / \mathrm{tography}$ is a living practice, involving life writing and life-creating experiences nourished by the personal, political and professional aspects of one's life. $\mathrm{A} / \mathrm{r} /$ tographers personally engage in the research, employing their artist, researcher, and/or teacher roles. They share their inquiries, practices and resulting understandings in the form of autobiographies, diaries, reflections, reflective writings, stories, comments and definitions [17].

A/r/tography has introduced six presentation concepts, namely: contiguity, living inquiry, metaphor, metonymy, openings and reverberations. However, these presentation concepts are not fixed characteristics or identifiers of $\mathrm{a} / \mathrm{r} /$ tography; they are proposed theoretical fields formed through exploring the artistic forms of research, knowing and being developed by Springgay, Irwin and Kind [17]. Any one of these concepts can be used in a/r/tography research and many more concepts can be unveiled during the $\mathrm{a} / \mathrm{r} /$ tography process.

In recent years, a variety of research has examined $\mathrm{a} / \mathrm{r} /$ tography. Springgay [13] conducted research as a visiting artist, researcher and coteacher. Her study applied the a/r/tography method in a secondary education art class where she modeled living inquiry and interaction, suggesting that students obtain knowledge by shaping art and communication through using their bodies openly and fluently as well as interacting with other bodies. The focus of Darts' [20] a/r/tographical research was defined as art education, which included students as social participants. In Darts' study, the participants were the researcher as well as 13 high school students. Using new approaches to encourage and prepare students, the study concluded that social and political links would strengthen student art, meaningfully involving them in public communication concerning culture and democratic citizenship. Barney [21] concentrated on how a/r/tography practices could be conceptualized in art classes. He studied this topic using the identity metaphor of dress in the classroom. In another study, Coleman [22] used a/r/tography, critical autoethnography and ethnographic video methods to understand how learning influences creativity and identity. He explored how learning happens in secondary school art education through a customized portfolio created during the process and product of developing creative practices; he assumed the role of an artist in order to see and notice particles generated throughout the artistic process. Shugurova [23]'s research defined the cultural and historic context of children's life experiences before starting compulsory education in Tibet; the research focused specifically on how children learn outside of the school environment and what their life learning experiences meant to them. Shugurova used a/r/tography as his study's methodological framework and concluded children's life learning styles included creative game playing, gender equal game playing, and intergenerational learning. Lee, Morimoto, Mosavarzadeh and Irwin's [24] study used walking as a form of inquiry in a working group dedicated to $\mathrm{a} / \mathrm{r} / \mathrm{tography}$ at the University of British Columbia. The research shows how walking and $\mathrm{a} / \mathrm{r} / \mathrm{tography}$ mutually reinforce one another and furthermore, examines three suggestions for doing so. This study concludes by stressing the importance of deeper reflection in being prepared for the totally unexpected.

The aforementioned research indicates that prior studies primarily focused on inquiries employing $\mathrm{a} / \mathrm{r} / \mathrm{tography}$ practices and life experiences. Although relevant research discusses how $\mathrm{a} / \mathrm{r} /$ tography practices are conceptualized in art education, such practices have not been studied from the perspectives of students taking the course and faculty members offering the course-it is important to evaluate this new method by applying these perspectives.

The main objective of this research is to identify the opinions of students and of faculty members offering courses on $\mathrm{a} / \mathrm{r} /$ tographical practices. In line with this main objective, the following sub goals are set in order to obtain detailed findings:

1. Through the lens of student opinions, evaluate how $\mathrm{a} / \mathrm{r} /$ tography practices contribute to students' artistic creation and production processes and the way such practices allow the artist/researcher/teacher-learner roles to emerge.

2. The goal is to identify the views of the faculty member offering Art Main Art Studio on contribution of $a / r /$ tography practices to the students and on its practicability.

\section{Methods}

\subsection{Research Patterns}

In this study, educational research was used to identify

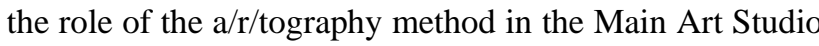
during art teacher training. As briefly mentioned above, 
although this method significantly resembles art-based educational research—qualitative research conducted by a school of experts-it is essentially an art-based living inquiry pattern that deals with meaning creation within the process rather than using the process to form conclusions.

\subsection{Study Group}

The study group consisted of 7 undergraduate students, 4 women and 3 men, enrolled at Gazi University as well as the Gazi Education Faculty in the Department of Fine Arts Education, Art Education Program, who took Art Main Art Studio in the spring semester of the 2016-2017 school year and the fall semester of the 2017-2018 school year as well as faculty members offering the course. Primarily to protect participants from undesirable approaches, pseudonyms are used to ensure anonymity [25]. The students in this study group are also involved in the research as a/r/tographers. 5 of the $\mathrm{a} / \mathrm{r} /$ tographers are 20 years old, while 2 of them are 21 . All of the a/r/tographers are Fine Arts High School graduates.

\subsection{Data Collection Tools and Process}

We collected research data using a semi-structured interview method both with students and with faculty members offering the course. The first step to prepare the interview questions was to scan relevant literature in the field. We then engaged in $\mathrm{a} / \mathrm{r} /$ tography practices with students. Out of the six presentation concepts, we selected metaphor and living inquiry, and also used knowing and exploration during application. We preferred to use living inquiry and metaphor since both concepts provide opportunities to experience life in different ways, which yield different viewpoints. They also help generate new meanings and inquiries through visual/written meanings and life experiences. To this end, students using $\mathrm{a} / \mathrm{r} /$ tography practices were asked to 1 ) pen their personal stories based on their life experiences, 2) generate meaning from these stories through metaphors, and 3) restate them as artworks. The participating students and faculty members offering the course were then interviewed.

Lawshe's content validity index was used for the interview questions. In Lawshe's technique, expert opinions are graded using the following statements: "the item measures the targeted structure", "the item is relevant to the structure but not necessary" or "the item is irrelevant to the targeted structure" for each item [26]. We ensured the concept validity of the interview questions by consulting with five experts. According to expert opinions, we excluded items that were problematic, insufficient and incongruous. The questions prepared for participating students were addressed to a student in his or her respective group; statements identified as unclear were revised. Interviews with faculty members were conducted separately in each faculty member's office, while student interviews were conducted individually in the studio.

\subsection{Data Analysis}

Descriptive analysis was used to analyze data obtained in this research, considering its suitability for structuring $\mathrm{a} / \mathrm{r} /$ tographic research. In analyzing data from the semi-structured interviews, the four stages of descriptive analysis were as follows: "establishing the framework of descriptive analysis", "data processing according to thematic framework", "description of findings" and "interpretation of findings" [27]. In the first stage, a framework was established based on the conceptual dimension of the research, practices and interviews. Next, themes were identified in order to present data within this framework - these themes were not question-based, rather they were obtained from the interviews as a whole. Additionally, during this second stage, researchers read semistructured interview responses at various times to make necessary arrangements. At this point, unnecessary data were eliminated. In the third stage, data obtained were described and directly quoted. In the last stage, the findings were explained, using a cause and effect relationship to build associations and interpretations.

\section{Findings and Discussion}

In this section, each finding is presented under its respective sub goal.

Sub goal 1: Through the lens of student opinions, evaluate the contribution of $\mathrm{a} / \mathrm{r} /$ tographical practices on students' artistic creativity and production processes as well as the way these practices help the artist/researcher/teacher-learner roles emerge. To this end, the following themes were identified and interpreted based on the analyzed interviews.

- Theme 1: Originality and creativity

- Theme 2: Establishing links with life experiences and artwork reflecting experiences

- Theme 3: Difficulty

- $\quad$ Theme 4: Development of artist/researcher/teacher-learner roles

\section{Theme 1: Originality and Creativity}

In an interview, $\mathrm{a} / \mathrm{r} /$ tographer Betül noted that she was in a constant state of thought from the beginning of $\mathrm{a} / \mathrm{r} /$ tographical practices to generate different ideas, which established a foundation for her own creative ideas. Betül noted that throughout her prior education, which was part of the Main Art Studio, she was never involved in a study that required thinking, generating ideas or producing original and creative works. Betül then claimed that during her college education, she had also not been encouraged to contemplate or been offered studies that required her to research or develop original thought. 
"The outstanding difference of this study was that it made us to think on generating original products ... Also, we were never required to carry out writing practices. It contributed to our thinking and idea generation. We could come up with more ideas and it was very useful for our creativity." (Betül)

A/r/tographer Metin stated that his opinions evolved unexpectedly as he wrote and thought about his own life, using the two $\mathrm{a} / \mathrm{r} /$ tographical practices. Metin likened $\mathrm{a} / \mathrm{r} /$ tography to film making and said that writing enabled him to explore small details about his experiences and thus create an original subject.

"Besides drawing, we also needed a scenario. We needed to write. After putting it in words, we needed materials to transform it into practice. That was the easiest part. The hardest part was to start writing and generating an idea... But the end result was great." (Metin)

Another interviewee, the a/r/tographer Serpil, also noted the immense contribution the practices offered her with respect to originality and creativity. Serpil added how she never thought about herself before-writing as part of the method gave her an opportunity to do so.

"Writing is not a practice we have been involved in before. The writing part was problematic for me because I am not good at it. But I would like it to continue because it helped us improve in the sense of both thinking and creativity." (Serpil)

$\mathrm{A} / \mathrm{r} /$ tographer Songül emphasized the contribution of the practices to their originality and noted how it improved their creativity. It is possible to say that producing artworks based on personal life experiences plays a key role.

$\mathrm{A} / \mathrm{r} /$ tographer Sule agrees with this thinking, stating that the practices contributed to her creativity. Şule also confided that, in starting a/r/tography, she was not fond of the idea generation process and found it challenging. She noted that, lack of similar practices in high school education and college programs had been responsible for this distaste.

"...metaphor; it created awareness in me by unveiling an unforgotten experience. Writing was very helpful for me in finding ideas. I would like it to continue." (Şule)

$\mathrm{A} / \mathrm{r} /$ tographer Fatih agreed with other students in that they had not used a creative method before and complained that it was the same in undergraduate education. On the other hand, Fatih noted that a/r/tography showed them how they can find specific ideas related to them.

"Going back to our own past or revisiting a past event that affected us was very effective in idea generation. ...It helped me find original ideas. When I had difficulty in finding ideas, I was able to bring out ideas thinking about myself." (Fatih)

As the students indicated, metaphor used in $\mathrm{a} / \mathrm{r} /$ tographical practices based on personal stories positively contributed to students' originality and creativity. According to contemporary cognitive linguists such as Lakoff and Johnson, metaphors arose from cognitive processes such as perception, memory, concept formation and behavior [28].

Moreover, students who claimed that the course was their first encounter with $\mathrm{a} / \mathrm{r} /$ tographical practices-life writing and metaphor creating-noted that such practices helped them develop their thinking, generate ideas, and produce original and creative work. As a result, the students became accustomed to a variety of perspectives as they determined meaning from their own perspectives. In fact, our main objective is to encourage students to generate their own meaning through encounters, allowing them to create multiple associations rather than present a single fact, because $\mathrm{a} / \mathrm{r} /$ tography emphasizes the previously unthought through messy, disturbing and complex processes.

Theme 2: Establishing links with life experiences and artwork reflecting experiences

A/r/tographer Betül claims that a/r/tographical practices contribute to establishing links with life experiences and artwork reflecting experiences, which establish the basis of $\mathrm{a} / \mathrm{r} / \mathrm{tography}$. She indicated that after she learned about life writing and metaphor (the two steps in $\mathrm{a} / \mathrm{r} /$ tographical practice), she started considering these steps in all of her work, which caused her to reflect on her own experiences and emotions-i.e., become aware of her own experiences. As a diary keeper in her personal life, Betül emphasized $\mathrm{a} / \mathrm{r} /$ tography's outstanding characteristics as follows:

"I have never imagined that a day would come when I would transform my words in my diary into practice and express them in the form of art. That is why I no longer perceive my diaries as mere records of memories; they are now study notes that have the potential to become artworks."

A/r/tographer Çağan also stated that he had never made practices based on his own life or experiences prior to $\mathrm{a} / \mathrm{r} /$ tographical practices. He also thought that these practices helped him become aware of his own experiences. Therefore, he completely agrees with Betül's affirmations.

$\mathrm{A} / \mathrm{r} /$ tographers Serpil and Songül agree that the distinguishing characteristic of the practices is that they enable one to establish links with life experiences and artwork reflecting experiences. They also add that this characteristic provides them with an opportunity to think and generate more ideas:

"I learned that I could use my past as the starting point of my artworks. I have started to think more on my past. When I started with this practice, I could come up with too many ideas and was able to change. I may even use them in the future." (Serpil)

"I learned how to examine my life, what I can transfer to art from my life and what I can take out from it. I also 
learned to be in constant communication with people and to pay attention to anything I go through and my experiences, to be able to establish links with life. In other words, I learned to live a life of awareness. I believe I can generate different metaphors about them in the future." (Songül)

As students' statements suggest, we conclude that $\mathrm{a} / \mathrm{r} /$ tographical practices contributed to their abilities so as to establish links with life experiences and further allow these life experiences to influence their artworks. Moreover, we can say that the practices helped students examine their lives more carefully, become aware of their experiences, and notice that they can find artistic subjects and meaning in everything. In research that is a journey of self-exploration through art making, writing, and sharing personal experiences, Golparian [29], in conclusion, suggests that one can create a house of one's own in self-created spaces, showing that generating meaning from personal experiences is a way of learning. Bateson [30] reminds us that "experience is the best teacher but a teacher many can't learn". Therefore, it is important to ensure that students are aware of such a teacher.

\section{Theme 3: Difficulty}

Student interviewees expressed that they experienced difficulties in certain stages of $\mathrm{a} / \mathrm{r} / \mathrm{tographical}$ practices. Indicating that the writing and idea finding stages were especially difficult for her, Songül said that she felt relieved once she completed these parts.

"I had difficulty in finding a subject, in other words, finding an idea and felt troubled in the process. Writing was also difficult for me. But once I found the subject, transferring it to my canvas was beautiful and time passed so quickly." (Songül)

The primary characteristic that distinguishes $\mathrm{a} / \mathrm{r} /$ tographical practices from other practices is that students write their own life experiences and use them to generate ideas. Transferring ideas into writing is similar to what they do regularly as part of their courses. Therefore, students did not experience difficulty in transference. As a regular diary keeper, Betül indicated that the writing stage was not difficult for her, but finding ideas was challenging.

"I just didn't know how prepared I was because I keep a diary.” (Betül)

$\mathrm{A} / \mathrm{r} /$ tographer Fatih also noted that it was difficult for him to find impressive things to say about himself. He also said that writing was a considerable challenge for him - he knew what to write about but found it challenging to express in writing. Although a/r/tographer Metin agreed with Fatih, he claimed that idea generation and writing were interrelated.

"[The] idea generation stage was difficult for me. ...Writing was also difficult. In fact, writing was associated with generating an idea. I would find an idea and write it. Then, I would find new ideas while writing

\section{and would write all over again.” (Metin)}

Finding generating ideas extremely challenging and indicating that they had some difficulty with writing, Serpil and Şule noted how relieved they felt when they completed those stages.

"Thinking and generating ideas, until I passed on to practice, was difficult for me because it is easier for me to proceed when I know what I will do." (Şule)

Almost every student indicated that the practices were difficult for them since the $\mathrm{a} / \mathrm{r} /$ tography method is based on generating ideas through using life writing and metaphor. This consensus mainly appears because education tends to be based on test work rather than on writing. When education is test-based, it gives readymade information to students instead of supporting independent idea generation. In traditional education methods, students increasingly write less and become passive receivers. Betül, a regular diary keeper in her personal life, was the only one comfortable with writing practice, further proving writing's importance. Pourchier [31] uses metaphor theories in her research that demonstrate how pedagogy is associated with writing, asserting that $\mathrm{a} / \mathrm{r} / \mathrm{tographical}$ inquiry initiates new possibilities.

Theme 4: The development of the artist/researcher and teacher-learner roles

$\mathrm{A} / \mathrm{r} /$ tographer Betül noted that using the $\mathrm{a} / \mathrm{r} /$ tography method was the first time she had ever felt involved in a real art project or practice and felt excited about it; she said that strong foundations were laid for her role as an artist. Betül also said that she had not undergone research for an artwork she had been creating before and pledged to make the deliberate research she found in this study a regular occurrence, emphasizing its benefits for her. Betül added that she developed a research habit in this process.

"I now think more before I start working, I have a look at my own life and prior studies. I used not to do that. I also comprehensively studied materials before I started my artwork. I learned about different materials. I achieved different perspectives. So, I felt like a real researcher in the process." (Betül)

Betül stated that she communicated with her friends constantly while using the method and gave them ideas from time to time, which made her feel like a teacher. On the other hand, Betül said that the learner role was predominant for her, so she learned to research and share ideas. Stressing how ultimately useful the practice was for her, Betül indicated that she grew both technically and cognitively in this process and believed she reflected on that progress as well.

$\mathrm{A} / \mathrm{r} /$ tographer Çağan, like Betül, noted that he felt more like an artist the more time he spent using the method. He believed that it was because participants could express their inner selves without copying others. Çağan said that he had to conduct more comprehensive research to better learn his 
subject better and that he had purchased, for the first time in his life, a book on his roots. In that sense, Çağan stressed that he felt like a researcher, underlining that there was "a lot he didn't know and took the opportunity to learn”.

A/r/tographer Fatih, on the other hand, said that the learner role stood out for him when he conducted research. Noting that he learned about how to find a subject through $\mathrm{a} / \mathrm{r} /$ tography, Fatih said he only experienced the teacher role when he gave minor suggestions to his friends. On the other hand, Fatih said he felt like a researcher throughout; he inquired about himself most overall, revisited the past often, and thought about his past experiences.

$\mathrm{A} / \mathrm{r} /$ tographer Metin emphasized that a/r/tography developed his role as an artist. He thought as and felt most like an artist during the exhibition stage. Metin also stated how the practices unveiled his curious personality, which was open to learning. He felt like a teacher when, as part of the method, he gave his friends ideas, aiming to teach them. Nonetheless, Metin added that he was constantly researching from the beginning to the end of the method, because he had to conduct more research for this method than for any other work in which he had been involved. Therefore, he most envisioned himself as a researcher.

"Even at the time we were preparing for the exhibition, I kept on researching to find out what else I could add to my painting. I made additions even in the last minute and my work looked more like an installation than a painting. So, I can say that my role as a researcher developed with this practice." (Metin)

$\mathrm{A} / \mathrm{r} /$ tographer Serpil indicated that throughout the practices, she felt like and considered herself a researcher, a student and a teacher. Serpil said that she tried to produce things by combining these roles, which was not something she felt often; she attributed this feeling to using $\mathrm{a} / \mathrm{r} /$ tography. Serpil also noted that her role as a researcher developed solely through these practices.

"In these practices, I researched myself. I thought about my past. Once I decided to work on camouflage, I started investigating what had been done about it before and what I can do. Consequently, I went as far as the starting point of camouflage, that is the nature. As I proceeded with application, I amply researched nature for photography shooting sessions.” (Serpil)

$\mathrm{A} / \mathrm{r} /$ tographer Songül, like Serpil, indicated that she felt like a researcher since she always researched subjects she had identified. Indicating that she indeed felt the learner role at all a/r/tographical stages, Songül said she learned a lot from her social circle, which caused her to realize that she could learn things at any moment throughout her life. Songül noted that she felt like a teacher when she was at the exhibition explaining her works and when people stopped to ask questions while she worked at the studio. She also noted that she also felt like an artist in the $\mathrm{a} / \mathrm{r} /$ tographical process.

"I thought of myself as an artist because I was reflecting on a section of my own life, doing something of my own and producing something new rather than a ready work." (Songül)

A/r/tographer Şule's statements parallel those of Songül at this point, proving how the practices contribute to developing students' roles as artists.

"My subject and the way I transferred it were my own and were original. I saw myself as an artist in that sense." (Şule)

$\mathrm{A} / \mathrm{r} /$ tographer Şule also noted that she envisioned herself as a teacher and learner throughout the practices. She said that she already offered others ideas and taught during classroom discussions, but she underlined that the practices offered more suitable ground for that. Additionally, Şule also stated that she considered herself a researcher during the $\mathrm{a} / \mathrm{r} /$ tographical process.

The students' statements above shed light on the practices' effectiveness in unveiling their roles as artists, since they could produce original artworks based on their personal lives. Additionally, in line with these statements, students worked collectively at times in the classroom through sharing comments and ideas, which helped them notice their teacher role. The act of teaching "creates openings for learning, development and change” [32].

Student statements concerning learning in the $\mathrm{a} / \mathrm{r} /$ tographical process stemmed from research activities, students' social circles, and other students, proving that their role as learners actively continued outside the classroom. Again, by guiding students to research, investigate and question their subjects throughout the process, the method effectively developed their roles as researchers. According to Kincheloe and Steinberg [33], students can be sophisticated researchers who generate their own knowledge and develop their own curriculum when a master teacher facilitates.

[...] a good education should prepare students as researchers who can 'read the world' in such a way so they not only can understand it but so they can change it. Students as researchers, as we envision them, possess a vision of 'what could be' and a set of skills to uncover 'what actually is'. [...] As our students as researchers progressively deepen their appreciation of the contradictory dynamics, they concurrently gain a power literacy. [...] Thus, students as researchers gain new ways of knowing and producing knowledge. [33]

Accordingly, we can also say that students could generate their own knowledge and produce new meanings, since the method encouraged them to conduct research.

Sub goal 2: To identify faculty members' offering the course views on Art Main Art Studio, specifically how $\mathrm{a} / \mathrm{r} /$ tographical practices contribute to students' education and its practicability. To this end, the following themes were identified and interpreted based on the interviews we analyzed.

- $\quad$ Theme 1: Originality and creativity 
- Theme 2: Effect on developing the artist/researcher and teacher-learner roles

- $\quad$ Theme 3: Difficulty

- $\quad$ Theme 4: Practicability

Theme 1: Originality and Creativity

The faculty member offering the course stated that students' ideas were quite original and creative and the artworks the practices helped them produce. The faculty member associated producing original work with students' inquiry into their own experiences and the self-analysis they achieved through writing. Thus, the faculty member offering the course emphasized the practices' distinguishing characteristics.

"[...] here, they came up with original ideas since they inquired their lives by writing and creating metaphors. Especially, the idea of the student who created a camouflage work using leaves to represent her military officer father, was beautifully developed. [...] Another student worked on the shutter image based on a childhood memory. That was another interesting idea. It was very interesting for the student who worked on the feeling of despair regarding rain to associate the experience with wet sidewalks. [...] Thus, the practices were effective in promoting original ideas."

The faculty member offering the course also indicated that the resulting pieces were beyond the students' capacity, although they were unfamiliar with $\mathrm{a} / \mathrm{r} /$ tographical practices.

"At the exhibition, we have received very positive feedback both from other faculty members and from other students. In fact, some faculty members thought that they were senior students. [...] In the end, they ended up with original and creative subjects about themselves. Without these practices, it could have been difficult for them to gravitate to those subjects. When the practices began, they were junior students who were accustomed to working according to the guidelines provided by and directions of their teachers back in fine arts high schools and were yet to get over that influence."

The faculty member offering the course who was, at the time, working on large portraits with the students, noted that when a subject was handed to students before the practices began, students could not generate ideas. On the other hand, after the practices started, students did not find it challenging to generate artistic manners of expression. This observation proves that the practices enhance student creativity.

We learn to write, draw, dance and sing to reintroduce the world as we know it. Our curiosity about the world is influenced by the tools that surround us. Language, like all $\mathrm{a} / \mathrm{r} /$ tographical presentation styles, does not just narrate the experience, it founds it. Language shapes our attention and furthermore, focuses and guides it [34]. In that sense, according to the faculty member offering the course, it is possible to say that writing, as used within the practices, provided students with the ability to create experiences as well as to re-experience and question their created products. Because life writing, like storytelling, creates opportunities to consider the effects of our actions and change our way of living, it is both a line of reasoning and a style of representation [35].

As the statements of the faculty member offering the course suggest, a/r/tographical practices gave students opportunities to generate meaning, pursue it and find their own ways of expressing it. Moreover, unlike dominant authority with defined limits, which does not encourage thinking and inquiry, a/r/tographical practices invited students to embark on a journey towards the unexpected as opposed to following fixed ideas and established perspectives. In light of statements of the faculty member offering the course, we can say that such an invitation effectively guided students to produce notably creative artworks compared to their previous works, despite being unaccustomed to the practices.

Leaving room for resistance, imagination, open capacity, creativity and surprise, the a/r/tographical approach to education and learning means that we deal with actions not behaviors. Action indicates taking initiative-moving forward to a future a participant can envision from an observation point. Action is concerned with beginnings not endings. Participants do not follow prescriptions; imposed, external assessments; or systematizations [36]. In this context, students are guided out of systematics through living inquiry and can explore such concepts as "taking the road less traveled", "constant trial" and "thinking outside of the box" in their creativity, as Özsoy [37] reminds us.

Theme 2: Effect on developing the artist/researcher and teacher-learner roles

The faculty member offering the course stressed that the practices revealed artist/researcher and teacher-learner roles of students simultaneously. The faculty member offering the course noted how the students researched as part of the practices like a researcher but added that such research did not have the features of a documentary, which lacks sufficient consideration of concepts and their philosophies. The faculty member offering the course thought that the students did not feel it was necessary to conduct such extensive research since, in the beginning, the students did not feel it was worthwhile to research experiences from their own pasts.

"In the beginning, they didn't feel highly about their past. However, our student who made the bicycle could have researched the history of bicycles, in fact movies on bicycles. There is so much to research, but they couldn't think about it. Again, the student who worked on toilets and went to his hometown to take pictures could go back to the historic roots. Generally, students were deficient researchers. Their curiosity was limited. That is actually 
because of the personal history of the students. They have never done such an inquiry before and their teachers always gave them directions. They have never expressed their own opinions before."

The faculty member offering the course also noted that students' failure to extensively research during the practices resulted from unfavorable habits adopted while in the educational system. In contrast, a/r/tography is integrated in the system as an act of inquiry and artistic application [38]. Moreover, artists' research does not involve strictly systematic research, nor is it solely "intuitive" (an unfortunate adjective that propagates a myth on how artists work). In fact, all artists' works require extensive, complex research [39]. In this context, although students did not perform systematic research that demonstrated documentary characteristics, they participated in research activities nonetheless, constituting a beginning for them and raising their awareness of research. This practice, in line with Meyer [40]'s course titled "Living Inquiry", did not provide education on research but only constituted an inquiry practice.

On the other hand, the faculty member offering the course also added that the students adopted artist attitudes while undergoing the practices; they thought like artists and further, some of them even developed considerably brave expressions. The faculty member offering the course deemed the resulting works beautiful and possessing great artistic value. The faculty member also noted that the students were learners in this process during and beyond course hours because the practices effectively caused their role as teachers to emerge as they supported one another and shared opinions.

In the $\mathrm{a} / \mathrm{r} /$ tography method, these roles are indeed interrelated and as a result, the processes of research, teaching-learning and art making are interconnected. These $\mathrm{a} / \mathrm{r} /$ tographical associations are derived from Deleuze and Guattari's [41] studies; they define how "rhizomes" are metaphorically interrelated through a network of interconnected roles, ideas and concepts. Like a network of lines on a roadmap, rhizomes do not contain beginnings or midsections; they only have links. Therefore, once the artist visualizes a series of strong roots that link the artwork with the writer, teacher and researcher, the gaps between apparently separate roles disappear, reinforcing all roles by allowing new ways/approaches/ideas to develop instead [42].

Although in general, students did not see much of a teacher role in themselves and teachers did not see much of a learner role in themselves, it is also a fact that, in Dewey's [43] words, "a teacher is a learner and a learner, however unknowingly, is a teacher".

\section{Theme 3: Difficulty}

Responding to the interview questions, the faculty member offering the course repeatedly discussed students' difficulty in the practices. The faculty member reasoned that the students were only juniors when the practices began, meaning that they were unable to think conceptually. The faculty member explained this lack of thinking and inquiry in their previous art education by stating that it was mostly didactic and focused on drawing what they saw. The faculty member stressed that students, as a result, were mostly interested in artworks' stylistic features and could not get accustomed to understanding thinking behind the artworks. In Chan's [44] study of preservice teachers' learning experiences, the researcher found a long-term influence that emerged from a didactic teaching and learning style-students became passive learners. Illustrating preservice teachers' passive learning styles, Chan narrated an account in which the students were asked about the most valuable learning outcome in the course. They were only asked to express their opinion-no answers were presented in the classroom. Most of the students had their heads down, apparently looking for the answers in the textbook, even though they were specifically told that there was no absolute answer.

Additionally, the faculty member offering the course indicated that the difficulty students experienced understanding the subject in the beginning of the practices was closely related to their cultural backgrounds.

"We understand that our students are not dedicated readers. They don't have strong links with literature or other fields of art or philosophy. Nobody in their lives guided them to read. So, they found the practice challenging."

The faculty member offering the course noted that the students also had difficulty at the stage of idea generation and stressed that it was because they never thought about themselves before and failed to face themselves in the beginning of the process.

"Of course, it is not easy to try to express oneself this way. The artworks, indeed, carry certain unintentional clues about experiences but in this practice, they were asked to do it consciously, conducting research and inquiries. So, in the beginning, students were afraid of making their cases. That may be because of value judgment of the society, that is, they might have thought that people would misjudge them."

Additionally, the faculty member offering the course indicated that the students had difficulty in the writing stage of the method, stressing that such difficulty results from the lack of similar writing practices in the Main Art Studio or other courses.

However, writing is a significant mode of self-expression. Writing encourages one to think, inquire and interpret. It is a means of expressing what we cannot express verbally about the past-our personal history and experiences. The words we use are, as Eisner [45] suggests, agents of first-hand experience when not used in artworks. In that sense, words are similar to directions we follow, showing us the way in a journey. The benefit of these 
directions depends on their ability to help us foresee what we wish to avoid or encounter. Courses can provide these to students in the form of living inquiry through $\mathrm{a} / \mathrm{r} /$ tography - in other words, through life writing in which art and writing are intertwined.

\section{Theme 4: Practicability}

The faculty member offering the course described $\mathrm{a} / \mathrm{r} /$ tographical practices as significant, because they teach students multilayered thinking. On the other hand, the faculty member offering the course underlined having undergone similar practices in the Main Art Studio without naming them; the faculty member added that these other practices did not penetrate as deeply as $\mathrm{a} / \mathrm{r} / \mathrm{tographical}$ practices. The faculty member offering the course also stated that a/r/tography would provide students with shortcuts to their experiences or to the subject of interest. To this end, on the practicability of $\mathrm{a} / \mathrm{r} / \mathrm{tographical}$ practices in Art Program, Main Art Studio, the faculty member expressed the following opinions:

"To be able to draw attention to experiences of students and to make it a part of their lives, a/r/tography practices should not only be a theme in Art Program, Main Art Studio, but it would be appropriate if it is given as a separate interdisciplinary/multidisciplinary course titled 'a/r/tographic thinking'. Because, practices under Art Program, Main Art Studio are limited to art painting. But nourishing the practice in different fields would be more beneficial for the development of students. For example, works of literature to be integrated with a musical piece or metaphors can be chosen."

As the faculty member offering the course suggests, use of a/r/tography practices as part of Art Program, Main Art Studio imposes limits on students. Although in the practices, students receive guidance for using different disciplines, they do not feel comfortable moving away from the limits presented in art painting. Due to the way Art Program, Main Art Studio is taught, students understandably perceive it as a painting exercise.

\section{Conclusions}

The conclusions reached in this study are listed below, categorized according to their respective sub goals:

\subsection{Conclusions Related to the First Research Sub Goal}

Based on students' opinions on a/r/tographical practices found in this study, we conclude the following:

All students believe that the $\mathrm{a} / \mathrm{r} /$ tographic artmaking and writing practices aim to generate ideas and that they should think all of the time, which leads to the rise of creative ideas. Additionally, according to the students, moving away from their own life experiences as part of the practices and as a result, noticing small details helped them create original works.

The students believe that creating meaning and artmaking based on their personal lives as part of the practices raised their awareness of life. In other words, they became aware of their experiences by reflecting on those experiences in art, which allowed them to live more intentionally.

Students indicated that they had difficulties in the idea generation, writing and forming meaning stages of the method. The only student who did not face writing challenges kept a diary in her personal life.

Students, in general, stated that they felt involved in an art project as a result of a/r/tographical practices - they felt like real artists working on subjects unique to them, using their own preferred methods. Students also noted that, throughout the practices, they were curious, inquisitive and investigative, which made them feel like researchers. Additionally, students stated that they were constantly learning and developing ideas during and outside of the studio, where they were always learners in the process, even though they felt like teachers at times when they shared ideas with one another. In this context, students believe that $\mathrm{a} / \mathrm{r} /$ tographical practices are effective in unveiling their roles as artists/researchers and teachers-learners.

\subsection{Conclusions Related to the Second Research Sub Goal}

Based on findings that stemmed from opinions of the faculty member offering the course on $\mathrm{a} / \mathrm{r} /$ tographical practices, we conclude the following:

The faculty member offering the course believes that allowing students to refer to their own experiences and life stories-while giving them the tool of life writing to do so-allows them to share original ideas. Additionally, the faculty member offering the course noted that the students produced artistic and creative works after such practices.

The faculty member offering the course stated that the students were involved in research activities, although that was not a documented research characteristic. The faculty member thinks that the practices required a certain level of research activity, but students were not involved in extensive research mainly, because students initially underestimated their own life experiences and even more importantly, the education system fails to guide students towards research. The faculty member believes that in the course's practices, students thought and acted as artists, producing works with high artistic value. Additionally, the students were learners throughout the practices both in and outside the studio; moreover, their roles as teachers were unveiled when they worked collaboratively and shared ideas with one another during the course.

The faculty member offering the course stated that the students had difficulty understanding the subject in the 
practices at first, since art education is not thought and inquiry-based. As a result, students' conceptual thinking skills are insufficiently developed. Noting that the students also found it challenging to find ideas, the faculty member claimed that they could not find ideas because students did not have the opportunity to contemplate their own experiences before. Moreover, noting the difficulty students experienced during the writing phase, the faculty member believes that students lacked similar practices in the Main Art Studio or other courses.

Despite finding the practices beneficial in that they develop multilayered thinking and raise awareness about experiences, the faculty member offering the course thinks that it would be beneficial if the course is offered separately as a theme under Art Program, Main Art Studio.

\section{Implications}

The following implications may be raised by our research conclusions:

- Considering the significance of life writing practices under $\mathrm{a} / \mathrm{r} /$ tographical thinking, idea generation and beginning awareness of experiences, such practices may be used with students in visual arts lessons starting during primary school education.

- Metaphor creation in $\mathrm{a} / \mathrm{r} /$ tographical practices may be used with students both in visual arts lessons and in lessons from other disciplines starting during preschool education.

- $\quad$ Students may be guided towards more inquiry and research in visual arts lessons at all educational levels starting during primary school education.

- Due to its thinking and inquiry approaches, $\mathrm{a} / \mathrm{r} /$ tographical practices are closely aligned with philosophy; therefore, high level thinking skills may be developed at all educational levels from preschool to university education. Considering this characteristic, a/r/tography courses could be included in all art teacher education preparation programs.

\section{Conflict of Interest}

As the authors of this research, we declare that no conflict of interest exists in our work.

\section{REFERENCES}

[1] R. L. Irwin. A/r/tography. In M. L. Buffington \& S. W. McKay (Eds.), Practice theory: Seeing the power of art teacher researchers (pp. 104-108). National Art Education Association, Reston VA, 2013.

[2] R. L. Irwin, D. T. Barney, S. Golparian. A/r/tografi, görsel araştırmalar için bir yöntem. In S. D. Bedir Eriști (Eds.), Görsel araştırma yöntemleri: Teori uygulama ve örnek (pp. 191-221). Pegem, Ankara, 2016.

[3] P. Leavy. Method meets art: Arts-based research practice, Guilford, New York, 2009.

[4] P. Leavy. Introduction to visual arts research special issue on a/r/tography. Visual Arts Research, Vol.38, No.2, 6-10, 2012.

[5] P. Leavy. Introduction to arts-based research. In P. Leavy (Eds.), Handbook of arts-based research (pp. 3-22). Guilford, New York, 2017.

[6] S. McNiff. Art-based research. In J. G. Knowles \& A. L. Cole (Eds.), Handbook of the arts in qualitative research: Perspectives, methodologies, examples, and issues (pp. 29-40). SAGE, Thousand Oaks CA, 2008.

[7] S. Wilson. Fragments life writing in image and in text. In R. Irwin \& A. de Cosson (Eds.), A/r/tography: Rendering self through arts-based living inquiry (pp. 41-59). Pacific Educational, Vancouver BC, 2004.

[8] T. Barone, E. W. Eisner. Arts-based educational research. In J. L. Given, G. Camilli \& S. B. Elmore (Eds.), Handbook of complementary methods in educational research (pp. 95-109). Routledge, New York, 2006.

[9] A. de Cosson. (Re)searching sculpted a/r/tography: (Re)learning subverted-knowing through aporetic praxis. Doctorate thesis, The University of British Columbia, Vancouver, BC, 2003.

[10] R. L. Irwin. Toward an aesthetic of unfolding in/sights through curriculum. Journal of the Canadian Association for Curriculum Studies, Vol.1, No.2, 63-78, 2003.

[11] R. L. Irwin. A/r/tography a metonymic métissage. In $\mathrm{R}$. Irwin \& A. de Cosson (Eds.), A/r/tography: Rendering self through arts-based living inquiry (pp. 27-38). Pacific Educational, Vancouver BC, 2004.

[12] S. Springgay. Cloth as intercorporeality: Touch, fantasy, and performance and the construction of body knowledge. International Journal of Education \& the Arts, 4(5). Online available from http://ijea.asu.edu/v4n5/ 2003.

[13] S. Springgay. Inside the visible: Youth understandings of body knowledge. Doctorate thesis, The University of British Columbia, Vancouver, BC, 2004a.

[14] S. Springgay. Body as fragment art-making, researching, and teaching as a boundary shift. In R. Irwin \& A. de Cosson (Eds.), A/r/tography: Rendering self through arts-based living inquiry (pp. 60-74). Pacific Educational, Vancouver BC, 2004b.

[15] R. L. Irwin, A. de Cosson. (Eds.). A/r/tography: Rendering self through arts- based living inquiry. Pacific Educational, Vancouver BC, 2004.

[16] S. Springgay, R. L. Irwin. Women making art: Aesthetic inquiry as a political performance. In A. L. Cole, L. Neilsen, J. G. Knowles \& T. C. Luciani (Eds.), Provoked by art: Theorizing arts-informed research (pp. 71-83). Backalong, Halifax, Nova Scotia, 2004.

[17] S. Springgay, R. L. Irwin, S. W. Kind. A/r/tography as living inquiry through art and text. Qualitative Inquiry, 
Vol.11, No.6, 897-912, 2005.

[18] T. T. Aoki. Spinning inspirited images in the midst of planned and live(d) curricula. In W. F. Pinar \& R. L. Irwin (Eds.), Curriculum in a new key: The collected works of Ted T. Aoki (pp. 414-423). Lawrence Erlbaum, New Jersey, 2005.

[19] N. Le Blanc, S. F. Davidson, J. Y. Ryu, R. L. Irwin. Becoming through $\mathrm{a} / \mathrm{r} /$ tography, autobiography and stories in motion. International Journal of Education Through Art, Vol.11, No.3, 355-374, 2015.

[20] D. G. Darts. Visual culture jam: Art, pedegogy and creative resistance. Doctorate thesis, The University of British Columbia, Vancouver, BC, 2004.

[21] D. T. Barney. A study of dress through artistic inquiry: Provoking understandings of artist, researcher, and teacher identities. Doctorate thesis, The University of British Columbia, Vancouver, BC, 2009.

[22] K. S. Coleman. An a/r/tist in wonderland: Exploring identity, creativity and digital portfolios as a/r/tographer. Doctorate thesis, Melbourne Graduate School of Education, Melbourne, 2017.

[23] O. Shugurova. A/r/tography of life learning: A historical perspective on children's lived experience and eco-cultural sustainability of childhood before the advent of compulsory schooling in Tibet. Journal of Unschooling and Alternative Learning, Vol.12, No.23, 19-55, 2018.

[24] N. Lee, K. Morimoto, M. Mosavarzadeh, R. L. Irwin. Walking propositions: coming to know a/r/tographically. International Journal of Art \& Design Education, Vol.38, No.3, 681-690, 2019.

[25] C. G. Christians. Ethics and politics in qualitative research. In N. K. Denzin \& Y. S. Lincoln (Eds.), The SAGE handbook of qualitative research (pp. 61-80). SAGE, Thousand Oaks CA, 2011.

[26] E. G. Gilbert, S. Prion. Making sense of methods and measurement: Lawshe's content validity index. Clinical Simulation in Nursing, Vol.12, 530-531, 2016.

[27] A. Yıldırım, H. Şimşek. Sosyal bilimlerde nitel araştırma yöntemleri. Seçkin, Ankara, 2013.

[28] D. Gillespie. Misreading Charlie: Interpreting a teaching story through metaphor analysis. McGill Journal of Education, Vol.40, No.1, 131-142, 2005.

[29] S. Golparian. Displaced displacement: An a/r/tographic performance of experiences of being unhomed. Doctorate thesis, The University of British Columbia, Vancouver, BC, 2012.

[30] M. C. Bateson. Foreword. In A. Neumann \& P. L. Peterson (Eds.), Learning from our lives: Women, research, and autobiography in education (pp. vii-viii). Teachers College, New York, London, 1997.
[31] A. N. M. Pourchier. Guided wanderings: An a/r/tographic inquiry into postmodern picturebooks, Bourdieusian theory, and writing. Doctorate thesis, Online available from https://scholarworks.gsu.edu/msit_diss/99 , 2012.

[32] S. Kind, A. de Cosson, R. L. Irwin, K. Grauer. Artist-teacher partnerships in learning: The in/between spaces of artist-teacher professional development. Canadian Journal of Education, Vol.30, No.3, 839-864, 2007.

[33] J. L. Kincheloe, S. R. Steinberg. Students as researchers: Critical visions, emancipatory insights. In S. R. Steinberg \& J. L. Kincheloe (Eds.), Students as researchers: Creating classrooms that matter (pp. 2-19). Falmer, London, 1998.

[34] E. W. Eisner. The enlightened eye: Qualitative inquiry and the enhancement of educational practice. Merrill, New Jersey, 1998.

[35] L. Richardson. Writing strategies: Reaching diverse audiences (qualitative research methods). SAGE, London, 1990.

[36] M. Greene. Releasing the imagination: Essays on education, the arts and social change. Jossey-Bass, San Francisco, 1995.

[37] V. Özsoy. Görsel sanatlar eğitimi, resim-iş eğitiminin tarihsel ve düşünsel temelleri. Pegem, Ankara, 2015.

[38] S. C. Kind. Of stones and silences: Storying the trace of the other in the autobiographical and textile text of art/teaching. Doctorate thesis, The University of British Columbia, Vancouver, BC, 2006.

[39] T. Barone. Science, art, and the predispositions of educational researchers. Educational Researcher, Vol.30, No.7, 24-28, 2001.

[40] K. Meyer. Living inquiry: Me, my self, and other. Journal of Curriculum Theorizing, Vol.26, No.1, 85-96, 2010.

[41] G. Deleuze, F. Guattari. A Thousand plateaus capitalism and schizophrenia (B. Massumi, Translate). University of Minnesota, Minneapolis, 2005.

[42] M. R. Carter, R. L. Irwin. Between signification and illumination: Unfolding understanding a/r/tographical turn on practicum. International Journal of Education \& the Arts, 15(3). Online available from http://www.ijea.org/v15n 3/, 2014.

[43] J. Dewey. Democracy and education an introduction to the philosophy of education. Macmillan, New York, 1963.

[44] E. Y. Chan. The transforming power of narrative in teacher education. Australian Journal of Teacher Education, Vol.37, No.3, 110-127, 2012.

[45] E. Eisner. Art and knowledge. In J. G. Knowles \& A. L. Cole (Eds.), Handbook of the arts in qualitative research: Perspectives, methodologies, examples, and issues (pp. 3-12). SAGE, Thousand Oaks CA, 2008. 